[Vol. 130:892

\title{
COMMENTS
}

\section{THE PROPRIETY OF REIMBURSEMENT BY MEDICARE FOR HILL-BURTON FREE CARE $\dagger$}

Over half of the hospitals in the United States ${ }^{I}$ have received construction funds under the Hill-Burton Act. ${ }^{2}$ Hospitals receiving such funds are required to make available "a reasonable volume of services to persons unable to pay therefor." 3 Unenforced and largely ignored for twenty-five years, ${ }^{4}$ the free care requirement was revitalized in the early 1970's, primarily as a result of a series of lawsuits by indigent persons who had been refused care by HillBurton aided facilities. ${ }^{5}$

The hospitals have attempted to lessen the impact of increased free care obligations in a number of ways, ${ }^{6}$ including seeking Medicare ${ }^{7}$ reimbursement for a portion of the cost of the free care. If

I After this Comment went to press, a House-Senate conference commitiee agreed on legislation amending the Social Security Act to prohibit Medicare reimbursement for Hill-Burton free care. See H.R. 4961, 97th Cong., 2d Sess. $\$ 106$, 128 Cong. Rec. H6171-72 (daily ed. Aug. 17, 1982).

1 Facts About the Hul-Burton Program, July 1, 1947-June 30, 1971, at 4 (HEW Pub. No. 72-4006, 1972), cited in Comment, Provision of Free Medical Services by Hill-Burton Hospitals, 8 HaRv. C.R.-C.L. L. REv. 351,352 n.9 (1973). Approximately 7000 medical institutions have received funding under the HillBurton Act. 44 Fed. Reg. 29,399 n.3 (1979).

2 Hospital Survey \& Construction Act, Pub. L. No. 79-725, 60 Stat. 1040 (1946) (current version at 42 U.S.C. $\$ \$ 291-2910$ (1976)).

342 U.S.C. $\$ 291 \mathrm{c}(\mathrm{e})(1976)$.

4 See Rose, Federal Regulation of Services to the Poor Under the Hill-Burton Act: Realities and Pitfalls, 70 Nw. U.L. Rev. 168, 172 (1975).

5 For a discussion of the influence of court action on the development of Department of Health and Human Services (HHS) policy, see id. 172-74; see also Note, Due Process for Hill-Burton Assisted Facilities, 32 VAND. L. Rev. 1469, 1473 (1979) [hereinafter cited as Due Process] (in response to judicial action, HEW issued regulations in 1972 and amended them in 1975).

- The American Hospital Association (AHA) recently has sought to enjoin enforcement of the 1979 regulations, arguing that the regulations placed an increased burden on the hospitals in violation of the due process clause. See American Hosp. Ass'n v. Harris, 625 F.2d 1328 (7th Cir. 1980) (denying the AHA's request for a preliminary injunction). The hospitals are not alone in criticizing the 1979 regulations. See, e.g., Due Process, supra note 5, at 1494-99; Note, The Hill-Burton Act, 1946-1980: Asynchrony in the Delivery of Health Care to the Poor, 39 Mo. L. Rev. 316, 318 (1979) [hereinafter cited as The Hill-Burton Act].

7 Title XVIII of the Social Security Act, popularly known as Medicare, was enacted as part of the Social Security Amendments of 1965. Pub. L. No. 89-97, $\$ \$ 1801-1875,79$ Stat. 299 (1965) (current version at 42 U.S.C. $\$ \$ 1395-1395 \mathrm{rr}$ (1976 \& Supp. III 1979)). Title XIX of the Social Security Act, popularly known 
the expense of providing free care is held to be an allowable cost, Medicare would reimburse hospitals for a percentage of the expense based on the proportion of Medicare patients they serve. ${ }^{8}$ The amount of money at issue is substantial. ${ }^{9}$

This Comment examines the propriety of reimbursement. The clash between the Medicare and Hill-Burton Acts forms the underlying controversy. The problem stems from Congress's failure to recognize and resolve the inconsistencies between the two Acts. Its failure to integrate the laws has led to conflicting results on the reimbursement issue. The Secretary of Health and Human Services (HHS) ${ }^{10}$ has consistently refused to classify Hill-Burton free

as Medicaid, which provides funding for medical care for the indigent, was also part of the Social Security Amendments of 1965. Pub. L. No. 89-97, \$\$19011905, 79 Stat. 343 (current version at 42 U.S.C. $\$ \$ 1396-1396 \mathrm{k}$ (1976 \& Supp. III 1979)). This Comment discusses Medicare reimbursement only. Historically, for inpatient purposes, Medicaid has followed the reimbursement principles of Medicare, although significant changes have occurred as a result of the 1981 amendments. Interview with Professor V. Edward Sparer, University of Pennsylvania School of Law (March 1982).

8 See infra Appendix and text accompanying notes 69-72. As the reimbursement scheme now stands, non-Medicare patients pay the entire cost of Hill-Burton free care. The hospitals essentially are seeking a new cost category, comprised of Hill-Burton free care expenses, to which the Medicare reimbursement percentage would be applied. See Iredell Memorial Hosp. v. Blue Cross Ass'n, [1981-1 Transfer Binder] Mentcare \& Medicam Gume (CCH) \30,930, at 9866, 9868 (Mar. 6, 1981), rev'd, 4 Medicare \& Medrcatd Gume (CCH) I 31,837, at 9207 (W.D. N.C. Jan. 7, 1982). That percentage would be based on the cost of care to Medicare patients compared to the cost to all other non-Fill-Burton patients. See infra Appendix.

${ }^{9}$ An assistant to the General Counsel of HHS estimated that if reimbursement were permitted, Medicare and Medicaid would cover $50-80 \%$ of the $\$ 400$ million worth of Hill-Burton free care provided each year. Florida Hosp. Group Appeal v. Blue Cross Ass'n, [1980 Transfer Binder] Medicare \& Medicam Gume (CCH) $\llbracket 30,374$, at 9415 (Dec. 17, 1979).

10 The Secretary of HHS has the overall responsibility for administering the Medicare program. The mechanism for reimbursing hospitals for care rendered to eligible persons is as follows: Hospitals (which, along with other providers of health care, are known simply as "providers") are reimbursed on a monthly basis by private "intermediaries," such as Blue Cross, for the estimated cost of the care. At the end of the fiscal year actual costs are determined and appropriate adjustments are made. If a provider disagrees with an intermediary's decision regarding reimbursement of a particular expense, it can appeal to the Provider Reimbursement Review Board (PRRB). A hearing is held before the four-member PRRB and a decision is rendered. A split decision has the effect of upholding the intermediary. The Secretary of HHS may, on his own motion, review the PRRB's decision within sixty days and modify or reverse it. (The Secretary has delegated that power to the Health Care Financing Administration (HCFA). Reorganization Order, 42 Fed. Reg. 13,262 (1977).) The provider may appeal either the PRRB's or HCFA's decision to the United States District Court. 42 U.S.C. $\$ 139500(f)$ (1976).

For a detailed description of the Medicare reimbursement and appeals process, see 2 MEDICARE \& MEDIGaId Gume (CCH) I7513, at 13,150-70, 13,470-540; 42 C.F.R. $\$ 405.452$ (1980). 
care as a reimbursable cost under Medicare.11 The federal courts, however, have split on the issue. ${ }^{12}$

This Comment contends that Medicare reimbursement is inappropriate for a variety of reasons. The fundamental reason is that reimbursement would be inconsistent with the purposes of both the Medicare and Hill-Burton Acts. Medicare was designed to provide health care financing for a specific class of persons-older

11 The PRRB originally held that reimbursement was improper. See, e.g., St. Francis Hosp., Inc. v. Blue Cross Ass'n, [1980 Transfer Binder] Medicare \& MEDrCaID Gume (CCH) $\llbracket 30,316$, at 9085 (Nov. 5, 1979); Indiana Hosp. Ass'n Group Appeal No. 4 v. Blue Cross Ass'n, [1979-2 Transfer Binder] Medrcare \& Medrcaid Gume ( $\mathrm{CCH}$ ) $\llbracket 30,133$, at 9894 (Sept. 18, 1979). Then for a time the PRRB split 2-2 on the issue. The effect of such a split is to uphold the decisions of the intermediary, which uniformly deny reimbursement. See, e.g., West Hudson Hosp. v. Blue Cross Ass'n, [1981-1 Transfer Binder] Medrcare \& Medrcato Gumb (CCH) $\llbracket 30,936$, at 9872 (Jan. 21, 1981); Metropolitan Medical Center \& Extended Care Facility v. Blue Cross Ass'n, [1981-1 Transfer Binder] Medicare \& Medrcam Gume (CCH) $\llbracket 30,891$, at 9717 (Oct. 7, 1980), rev'd, 524 F. Supp. 630 (D. Minn. 1981). After the Fifth Circuit's decision in Presbyterian Hosp. v. Harris, 638 F.2d 1381 (5th Cir.), cert. denied, 102 S. Ct. 476 (1981), the PRRB began to vote 3-1 in favor of reimbursement in a series of cases beginning with John Muir Memorial Hosp. v. Blue Cross Ass'n, [1981-2 Transfer Binder] Medicare \& MEDICAm GUIDE (CCH) If 31,492, at 9443 (Aug. 26, 1981). See also Gaston Memorial Hosp., Inc. v. Blue Cross Ass'n, [1981-82 Transfer Binder] Medicare \& Medicam Gume (CCH) I 31,545, at 9686 (Sept. 11, 1981).

HCFA, however, has consistently refused to permit reimbursement, see, e.g., [1981-1 Transfer Binder] Medicare \& Medicamo GumE (CCH) fI 30,854-56, at 9640-42, and has reversed the latest PRRB decisions. See, e.g., Gaston Memorial Hosp., Inc. v. Blue Cross Ass'n, [1981-2 Transfer Binder] Medrcare \& Medicam Gume (CCH) $\{31,637$, at 10,108 (Nov. 7, 1981). But HCFA recently held that, with respect to providers located in the Fifth Circuit, Hill-Burton free care is reimbursable by Medicare. See Harris Hosp. v. Blue Cross Ass'n, [1981-2 Transfer Binder] Medicare \& Medicam Gume (CCH) \31,638, at 10,114 (Dec. 11, 1981). The deputy administrator felt constrained by the ruling in Presbyterian, noting that "[d]espite the Court's decision in that case ... [he] believes in the continued validity of Medicare reimbursement policy that ... [Hill-Burton free care is] not reimbursable by Medicare ...." Id. $\llbracket 31,638$, at 10,115 .

12 The issue first reached the federal courts in Rapides Gen. Hosp. v. Matthews, 435 F. Supp. 384 (W.D. La. 1977) (holding that reimbursement was required), vacated and remanded on other grounds, No. 77-3125 (5th Cir. Oct. 23, 1978) (unpublished order) (the decision was vacated because the hospital had provided no free care in the year in question, but simply had created an accounting entry). In Presbyterian Hosp. v. Harris, 638 F.2d 1381 (5th Cir.), cert. denied, $102 \mathrm{~S}$. Ct. 476 (1981), the court followed the reasoning in Rapides in holding that reimbursement was required. Id. 1386-87. Since the holding in Presbyterian, the district courts that have considered the issue have split 4-2 in favor of reimbursement. Cases holding reimbursement proper are: Iredell Memorial Hosp., Inc. v. Schweiker, 4 MEDICARE \& MEDICADO GUIDE (CCH) II 31,837, at 9207 (W.D.N.C. Jan. 7, 1982); Johnson County Memorial Hosp. v. Schweiker, 527 F. Supp. 1134 (S.D. Ind. 1981); St. James Hosp. v. Harris, [1981-2 Transfer Binder] Medicare \& Medicam GumE (CCH) I 31,630, at 10,075 (N.D. IIl. Dec. 4, 1981); Metropolitan Medical Center v. Harris, 524 F. Supp. 630 (D. Minn. 1981). Cases upholding denial of reim. bursement are: Saint Mary of Nazareth Hosp. Center v. HHS, 4 Medicare \& Medicaw Gume (CCH) $\int 31,821$, at 9108 (N.D. Ill. Jan. 14, 1982); Harper-Grace Hosp. v. Schweiker, [1981-1 Transfer Binder] MEDICARE \& Medicam Gunde (CCH) If 31,037, at 10,216 (E.D. Mich. Apr. 1, 1981). 
Americans. ${ }^{13}$ Permitting reimbursement would conflict with the limited scope of the Act as well as the reimbursement scheme of Medicare. ${ }^{14}$ Additionally, reimbursement would be inconsistent with the intent of the Hill-Burton Act. ${ }^{15}$ As a condition for receiving federal funds for construction of facilities, hospitals agreed to provide a reasonable volume of free care to the indigent. If Medicare reimburses the hospitals, they will in effect be shifting back to the federal government a portion of the obligation that they agreed to assume. Finally, there are sound policy reasons for refusing reimbursement-the most important being that reimbursement would reduce the total volume of care available to the poor.

The first part of this Comment addresses the propriety of reimbursement under Medicare principles. The two theories of reimbursement-as an interest expense on construction loans or as an indirect cost of service-will be examined. The conflict between these theories of reimbursement and the current regulations, the statutory provisions, and the basic cost principles and overall purposes of Medicare will be discussed.

If Medicare principles preclude reimbursement, then what the Hill-Burton Act allows is irrelevant because there is no other existing source of funds for such large-scale reimbursement. If the Medicare Act permits reimbursement, however, part II, which examines the propriety of reimbursement in light of the Hill-Burton Act, becomes essential to an analysis of the issue. Part II first demonstrates that reimbursement conflicts with existing Hill-Burton regulations. It then shows that reimbursement would contravene the general purpose of the Hill-Burton Act. Finally, part III examines overall policy considerations underlying the reimbursement issue.

\section{The Propriety of Reimbursement under Medicare}

The issue of reimbursement for free care provided pursuant to Hill-Burton obligations implicates two fundamental principles of Medicare. The first is that Medicare reimburses for both the direct and indirect costs of providing service. ${ }^{16}$ The second is that costs should be calculated so that "the necessary costs of efficiently delivering covered services to individuals covered by [Medicare] will not be borne by individuals not so covered, and the costs with

13 See supra note 7.

14 See infra text accompanying notes 63-83.

15 See infra text accompanying notes 98-123.

1642 U.S.C. $\$ 1395 \times(v)(1)(A)(1976)$. 
respect to individuals not so covered will not be borne by [Medicare]." ${ }^{17}$ The reimbursement question reflects the tension between these two principles. Hill-Burton free care is provided to individuals who are not covered by Medicare, ${ }^{18}$ indicating that reimbursement is not proper under the second principle. The providers, ${ }^{19}$ however, argue that Hill-Burton care properly should be considered an indirect cost of providing service to all patients, including Medicare patients. ${ }^{20}$ The propriety of reimbursement, at least as an issue under Medicare rather than Hill-Burton, depends on a resolution of the conflict between these two principles.

\section{A. Hill-Burton Free Care as "Interest" on Construction Loans}

Consistent with the principle that Medicare covers both direct and indirect costs, the regulations provide that "[n]ecessary and proper interest on both current and capital indebtedness is an allowable cost." ${ }^{21}$ Some hospitals have attempted to recover the cost of Hill-Burton free care as an interest expense on capital indebtedness. ${ }^{22}$ The providers' argument is as follows. The costs of Hill-Burton free care are an expense of receiving Hill-Burton funds. Providing free care to the indigent qualifies the hospital for an interest subsidy (or grant). Without that subsidy, the hospitals would be required to pay the full market rate of interest on construction loans-an amount that Medicare, in turn, would fully reimburse. The cost of providing free care is simply in lieu of interest payments and is therefore equivalent to interest. ${ }^{23}$

The attempt to recover Hill-Burton free care as an interest expense, however, has been uniformly rejected by the Provider Reimbursement Review Boards (PRRB), ${ }^{24}$ the Health Care Financ-

$17 \mathrm{Id}$.

18 The hospital cannot be reimbursed for care provided to individuals who are eligible for Medicare. See infra note 89 and accompanying text. In addition, patients have no incentive to request Hill-Burton free care if they know that Medicare will reimburse most of the cost of their medical care.

19 Hospitals and medical centers are known as "providers."

20 E.g., Rapides Gen. Hosp, v. Matthews, 435 F. Supp. 384, 388 (W.D. La. 1977), vacated and remanded on other grounds sub nom. Rapides Gen. Hosp. v. Califano, No. 77-3125 (5th Cir. Oct. 23, 1978) (unpublished order).

2142 C.F.R. $\$ 405.419$ (a) (1981).

22 See, e.g., Indiana Hosp. Ass'n Group Appeal No. 4 v. Blue Cross Ass'n, [1979-2 Transfer Binder] Medicare \& MEDiCAD GuIDE (CCH) $\llbracket 30,133$, at 9894 (Sept. 18, 1979).

23 Id. 9896.

24 See, e.g., id. 9898. For a description of the PRRB, see supra note 10. 
ing Administration (HCFA), and the courts ${ }^{25}$ as inconsistent with the regulations. ${ }^{26}$ To be reimbursable, interest expenses must be "necessary" and "proper." 27 The definition of proper requires that interest "[b]e paid to a lender not related through control or ownership, or personal relationship to the borrowing organization." 28 Because Hill-Burton care is not "paid to a lender," it cannot be considered interest under the regulations. ${ }^{29}$ Even those courts holding that Hill-Burton care should be considered an indirect and hence reimbursable cost have held that the absence of ambiguity in the language of the regulation compels the conclusion that Hill-Burton care is not interest. ${ }^{30}$

Although strict reliance on the language of the regulations is open to criticism, ${ }^{31}$ the refusal to classify Hill-Burton care as interest is sound. Such a classification stretches the concept of interest too far. In the case of grants, the free care cannot be considered interest when no funds have been borrowed. In the case of interest subsidies, the federal government via the Hill-Burton program, not the hospital, pays the interest on the borrowed funds. Hospi-

25 For a HCFA decision, see Metropolitan Medical Center \& Extended Care Facility v. Blue Cross Ass'n, [1981-1 Transfer Binder] Medicape \& MEDICAW Gume (CCH) $\int 30,891$, at 9717 (Oct. 7, 1980), rev'd, 524 F. Supp. 630 (D. Minn. 1981). For federal courts that have ruled on the issue, see supra note 12. For a description of HCFA, see supra note 10.

2642 C.F.R. $\$ 405.419$ (b) (1981) provides:

(b) Definitions-(1) Interest. Interest is the cost incurred for the use of borrowed funds. ... .

(2) Necessary. Necessary requires that the interest:

(i) Be incurred on a loan made to satisfy a financial need of the provider. ...

(3) Proper. Proper requires that interest:

(ii) Be paid to a lender not related through control or ownership, or personal relationship to the borrowing organization.

(emphasis added to $\$(3)$ (ii)).

2742 C.F.R. $\$ 405.419(\mathrm{a})$ (1981).

28 Id. $\$ 405.419(\mathrm{~b})$.

29 Rapides, 435 F. Supp. at 387. In the case of Hill-Burton grants, as opposed to interest benefits, the regulations also preclude reimbursement because the costs are not "incurred on a loan" nor are they "incurred for the use of borrowed funds." See 42 C.F.R. $\$ \$ 405.419$ (b) (2) (ii), 405.419(b) (1) (1981).

30 See Rapides, 435 F. Supp. at 387; see also Presbyterian Hosp. v. Harris, 653 F.2d 1381, 1387 (5th $\mathrm{Cir}$.) ("free care expenses are not 'interest' within the meaning of the regulations"), cert. denied, 102 S. Ct. 476 (1981).

31 The providers argue that the purpose of the requirement that interest be paid to a lender unconnected to the hospital is to prevent self-dealing and to insure that borrowing is conducted at arms length. Because that purpose is not implicated by reimbursement in this instance, reliance on the literal language of the statute is misplaced. See Indiana Hosp., [1979-2 Transfer Binder] MEDICARE \& Medrcam Gume (CCH) \30,133, at 9896 . 
tals are on firmer ground in arguing that Hill-Burton expenses are not interest per se, but rather an expense closely analogous to interest that should be reimbursed as an indirect cost.

\section{B. Reimbursement as an Indirect Cost of Improved Health Care Facilities}

\section{The Argument That Hill-Burton Free Care Is a Reimbursable Cost}

The hospitals' inability to tie successfully their reimbursement argument to a specific cost category, such as interest, does not end the inquiry. The regulations that define reimbursable cost reflect the statutory requirement that both direct and indirect costs ${ }^{32}$ associated with the provision of services to eligible persons be included. $^{33}$ Thus, the hospitals argue that Hill-Burton care, if not technically "interest," is analogous to interest, depreciation, or other reimbursable costs..$^{34}$ The Hill-Burton care, although not provided to Medicare beneficiaries, benefits the entire patient population, including Medicare patients, by qualifying the hospital for funds to replace or improve its facilities. Because the Medicare patients benefit from the facilities, it is only fair that they-through Medicare reimbursement-should pay their share of the cost. The courts in Rapides General Hospital v. Matthews ${ }^{35}$ and Presbyterian Hospital $v$. Harris ${ }^{36}$ found this straightforward argument persuasive.

Although the argument does possess a certain logic, it must be rejected as inconsistent with the current regulations, the statutory language, reimbursement principles, and the overall purpose of Medicare.

32 Direct costs are those associated with the actual delivery of care to patients, such as physician and nurse salaries and the cost of equipment, pharmaceuticals, and utilities. Indirect costs are more general expenses of the business, such as interest on loans, depreciation, and the return on equity capital of proprietary hospitals.

33 (3) The determination of reasonable cost of services must be based on cost related to the care of beneficiaries of title XVIII of the Act. . . . It includes both direct and indirect costs and normal standby costs. However, where the provider's operating costs include amounts not related to patient care, specifically not reimbursable under the program ... such amounts will not be allowable.

42 C.F.R. $\$ 405.451$ (c)(3) (1981).

34 Rapides, 435 F. Supp. at 388; see Brief of Plaintiff-Appellant at 13-21, Harper-Grace Hospitals v. Schweiker, No. 81-1305 (6th Cir.) (date brief submitted July 14, 1981). Reimbursement for depreciation is provided for in 42 C.F.R. $\$ \$ 405.415-.418$ (1981).

35435 F. Supp. at 388.

36638 F.2d 1381, 1386-87 (6th Cir. 1981). 


\section{Reimbursement Is Prohibited by the Medicare Regulations and Statutes}

The definition of reasonable (reimbursable) cost in the regulations excludes costs "specifically not reimbursable under the [Medicare] program. ..." ${ }^{37}$ Thus, even assuming that Hill-Burton care is a legitimate indirect cost, reimbursement is arguably prohibited by the regulation precluding reimbursement for charity care ${ }^{38}$ and by the statutory provision that prohibits reimbursement for services for which the patient has no legal obligation to pay. ${ }^{39}$

\section{a. Charity Care Is Not a Reimbursable Cost}

Medicare regulations have provided from the outset that bad debts, charity, and courtesy allowances are not to be included as allowable costs. ${ }^{40}$ HHS has consistently taken the position that the charity exclusion applies to Hill-Burton free care. ${ }^{41}$

The providers and two dissenting PRRB members dispute this interpretation, relying on a literal interpretation of the term "charity." They argue that care provided to the indigent to fulfill HillBurton obligations cannot be considered charity because it is not "voluntary." 42 Although the original Hill-Burton regulations were

$$
\begin{aligned}
& 3742 \text { C.F.R. } \$ 405.451 \text { (c)(3) (1981). } \\
& 3842 \text { C.F.R. } \$ 405.420 \text { (a) (1981). } \\
& 3042 \text { U.S.C. } \$ 1395 y(a)(2)(1976) \text {. }
\end{aligned}
$$

40 The original regulations were published at 31 Fed. Reg. 14,813 (1966) (codified at 42 C.F.R. $\$ 405.420$ (1981)). The current regulations are substantially the same in relevant part:

(a) Principle. Bad debts, charity, and courtesy allowances are deductions from revenue and are not to be included in allowable cost . . . .

(b) Definitions ....

(2) Charity allowances. Charity allowances are reductions in charges made by the provider of services because of the indigence or medical indigence of the patient.

(c) Normal accounting treatment: Reduction in revenue. Bad debts, charity, and courtesy allowances represent reductions in revenue. The failure to collect charges for services rendered does not add to the cost of providing the services. Such costs have already been incurred in the production of the services.

42 C.F.R. $\$ 405.420$ (1981).

41 See, e.g., Indiana Hosp., [1979-2 Transfer Binder] MEDICARE \& MEDICAm Gume (CCH) I 30,133, at 9898-99; Harper Hosp. Div. v. Blue Cross Ass'n, [1980 Transfer Binder] Medicare \& MediCam Gume (CCH) 『30,456, at 9789 (Feb. 21, 1980).

42 Indiana Hosp., [1979-2 Transfer Binder] Medrcare \& Medicam Gume (CCH) II 30,133, at 9896, 9900 (dissenting opinion of H. Joseph Curl). Subsequently, James Houdek joined Curl in dissenting on these grounds. See, e.g., Iredell Memorial Hosp. v. Blue Cross Ass'n, [1981-I Transfer Binder] MEDICARE \& MedrCAm Gume (CCH) 【 30,930, at 9866, 9868-69 (Mar. 6, 198I), rev'd, 4 Medicare \& Medicam Gume (CCH) đ31,837, at 9207 (W.D.N.C. Jan. 7, 1982). 
precatory with respect to the provision of free care, subsequent regulations ${ }^{43}$ and court rulings have transformed the provision of free care into a definite legal obligation. ${ }^{44}$ The argument is now complete: because free care is legally required, it is not a voluntary act and therefore cannot be considered charity. The courts holding that reimbursement is proper have accepted this analysis. ${ }^{45}$

Superficially, the providers' argument appears persuasivecharity normally presupposes voluntarism. This argument, however, does not withstand closer scrutiny. Resort to the dictionary definition of charity is inappropriate because the regulation provides its own definition of the term: "Charity allowances are reductions in charges made by the provider of services because of the indigence or medical indigence of the patient." ${ }^{46}$ The definition is not limited to voluntary reductions in charges; it simply refers to reductions made because of indigence. Hill-Burton beneficiaries are by definition indigent or medically indigent. ${ }^{47}$

The inclusion of Hill-Burton care in the charity exclusion is supported by more than a literal reading of the language of the regulation. The existence of the free care obligation, although admittedly not in the more structured form it ultimately took, predated the charity provision.48 An exception to the definition of charity that would permit reimbursement for Hill-Burton care could have been written into the regulation easily. ${ }^{40}$

The inclusion of Hill-Burton free care as charity is consistent with the other forms of charity included in the definition. HillBurton free care may be a legal obligation, but so may free care provided pursuant to requirements of a local or state statute. Providing charity care to the indigent may be "involuntary" for some

43 See supra notes 5-9. See also Indiana Hosp., [1979-2 Transfer Binder] Medrcare \& Medicam Gume (CCH) \30,133, at 9900 ( $\mathrm{H}$. Joseph Curl, dissenting, noting that " $[t]$ he amount of the free care at the time of passage of ... Hill-Burton ... was vaguely stated but subsequent regulations have clarified both the amount of the care and the manner in which it will be delivered").

44 Saine v. Hospital Auth., 502 F.2d 1033 (5th Cir. 1974); Euresti v. Stenner, 458 F.2d 1115 (10th Cir. 1972) (the indigent may bring a civil action to compel Hill-Burton aided facilities to comply with free care obligations).

45 See, e.g., Johnson County Memorial Hosp. v. Schweiker, 527 F. Supp. 1134, 1140-41 (S.D. Ind. 1981); Metropolitan Medical Center v. Harris, 524 F. Supp. 630, 634 (D. Minn. 1981).

4642 C.F.R. $\$ 405.420$ (b)(2) (1981).

4742 C.F.R. $\$ 124.506$ (1981) details the criteria for defining those persons unable to pay for health care.

48 Harper-Grace Hosp. v. Schweiker, [1981-1 Transfer Binder] MEdicare \& Medrcam Gume (CCH) fil,037, at 10,216, 10,218 (E.D. Mich. Apr. 1, 1981).

49 Cf. NLRB v. Bell Aerospace Co., 416 U.S. 267, 274-75 (1974) (courts may place great weight on longstanding agency interpretation of a statute where Congress has reenacted the statute without pertinent change). 
hospitals in that it may be required by the hospitals' charters. ${ }^{.0}$ Free care also may be involuntary in the sense that it is often required in order to qualify the institution for a favorable tax status. ${ }^{51}$ The varying motivations for providing free care do not prevent its classification as charity; the attempt to distinguish Hill-Burton from other forms of charity on the basis of voluntarism, therefore, is illfounded. ${ }^{52}$ The hospitals' objection is more appropriately directed at the policy on reimbursement for charity care, bad debts, and courtesy allowances, rather than at the inclusion of Hill-Burton care within the definition of charity. As will be shown, however, the exclusion of free care from reimbursement is consistent with Medicare cost principles as well as with the purpose of the Medicare Act.

\section{b. The Medicare Act Directly Prohibits Reimbursement for Hill-Burton Care}

Reimbursement for Hill-Burton care is prohibited not only by the charity exclusion but also by an express prohibition in the Medicare Act that states: " $[\mathrm{N}] \mathrm{o}$ payment may be made under [Medicare] for any expenses incurred for items or services ... for which the individual furnished such items or services has no legal obligation to pay, and which no other person . . . [because of, e.g., a prepayment plan] has a legal obligation to provide or pay for." 53 Recipients of Hill-Burton free care are not legally obligated to pay for the services they receive. ${ }^{54}$ The Health Care Finance Administrator has reversed PRRB decisions allowing Medicare reimburse-

50 Cf. Orange County v. Orlando Osteopathic Hosp., 66 So. $2 d$ 285, 286, 288 (Fla. 1953) (hospital's policy was not to deny treatment to any patient because of inability to pay).

51 See Bromberg, The Charitable Hospital, 20 Catr. U.L. Rev. 237, 237 (1970). See generally Comment, Federal Income Tax Exemption for Private Hospitals, 36 FordhaM L. REv. 747 (1968).

52 The legislative history does not distinguish between types of free care based on the motivation for providing the care. Rather, it refers generally to the provision of care to those unable to pay, including charity and indigent patients. S. ReP. No. 404, 89th Cong., lst Sess. 36-37 (1965), reprinted in 1965 U.S. Code Conc. \& AD. NEws 1943, 1977-78. The status of charity care as a "reduction in revenue" rather than an additional cost provides added support for including HillBurton care within the definition. See infra text accompanying note 55 . As a matter of cost accounting there is no difference between Hill-Burton and other forms of charity care.

5342 U.S.C. $\$ 1395 y(a)(2)$ (1976).

54 A premise of the providers' argument that Hill-Burton care is not charity is that the hospitals have no right to collect for uncompensated services rendered under Hill-Burton. Indiana Hosp., [1979-2 Transfer Binder] MEDicare \& Medrcam GuIDE (CCH) I 30,133, at 9896. 
ment, relying on this express statutory exclusion. ${ }^{55}$ The courts that have addressed the issue to date have split. In Saint Mary of Nazareth Hospital Center $v . H H S$, , $H$ the court held that the "blanket prohibition against payment from Medicare funds for certain services . . . clearly encompasses the Hill-Burton free care costs since by definition the indigents who received [the] care were not obligated to pay for it." In Iredell Memorial Hospital, Inc. v. Schweiker, ${ }^{57}$ the court reached a contrary result. Although the court agreed that the Hill-Burton patients have no legal obligation to pay for their care, it found the second clause of the section, which requires that no other person have a legal obligation to provide or pay for the patient's care, controlling on the issue. The court reasoned that the hospital itself had a legal obligation to provide the care under the Hill-Burton Act and therefore the section did not bar reimbursement.58 Significantly, the court elsewhere in the opinion also declared that hospitals have no legal obligation to pay for the care that they provide pursuant to Hill-Burton obligations..$^{59}$

The court's distinction between "pay for" and "provide" is somewhat strained. Nothing in the limited legislative history suggests that Congress drew such a distinction. ${ }^{60}$ Rather, the terms "pay for" and "provide" were probably equivalent, the latter being included simply to make clear that prepayment plans will not be affected by the exclusion.

The Medicare \& Medicaid Guide suggests another argument against applying the exclusion to Hill-Burton. It notes that the exclusion is properly understood as referring only to those services provided to anyone without charge, such as free chest $\mathrm{x}$-rays or blood pressure tests: "This exclusion does not apply where items and services are furnished an indigent individual without charge because of his inability to pay, if the provider, physician, or supplier bills other patients to the extent that they are able to pay." 61

55 Gaston Memorial Hosp., Inc. v. Blue Cross Ass'n, [1981-2 Transfer Binder] Medicare \& Medrcam Gume (CCH) $\Uparrow 31,637$, at 10,108, 10,111 (Nov. 7, 1981), rev'g Gaston Memorial Hospital, Inc. v. Blue Cross Ass'n., [1981-2 Transfer Binder] MEDICARE \& MEdICAJ GUIDE (CCH) I 31,545, at 9686 (Sept. 11, 1981).

564 Medicare \& MeDicam Gume (CCH) \31,821, at 9108, 9110 (N.D. Ml. Jan. 14, 1982). 1982).

574 Medicare \& Medicam GuDE (CCH) \ 31,837, at 9207 (W.D.N.C. Jan. 7,

58 Id. \f 31,837 , at 9210 .

59 Id.

60 See S. Rap. No. 404, 89th Cong., Ist Sess. 36-37, $48-49$ (1965), reprinted in 1965 U.S. CODE CoNG. \& AD. NEws 1943, 1977-78, 1989-90.

611 MEDICARE \& MEDICAm Gume (CCH) If 4035.33, at 1414. 
No cases are cited to support this interpretation. The only example cited in the legislative history-free chest $\mathrm{x}$-rays provided by health organizations-is consistent with the Guide interpretation. ${ }^{62}$

The language of the exclusion, focusing as it does on the nature of the obligation of the individual or other party to pay rather than on the type of service provided, seriously undercuts the Guide interpretation. But both the court's analysis in Iredell and the Guide interpretation raise sufficient doubt about the proper interpretation of the exclusion to make appropriate a consideration of the propriety of Hill-Burton reimbursement under the general principles of Medicare.

\section{G. Reimbursement for Hill-Burton Care Contravenes the Fundamental Principles of Medicare}

The exclusion of Hill-Burton care from reimbursement is rooted in the basic purpose of the Medicare Act. Medicare was designed not as a universal national health plan, but as a limited plan to benefit only certain categories of people. ${ }^{63}$ This intention finds expression in the Act's provision that "the necessary costs of efficiently delivering covered services to individuals covered by [Medicare] will not be borne by individuals not so covered, and the costs with respect to individuals not so covered will not be borne by [Medicare]." 64 This focus on the status of the recipient of the care provides a basis for the general charity exclusion and the denial of reimbursement for Hill-Burton care. ${ }^{65}$ The rationale that free care is provided to ineligible persons (persons "not so covered") and therefore is not a reimbursable cost under Medicare, however, was presented to and rejected by the court in Rapides:

Plaintiff does not assert that the free care beneficiaries are medicare recipients and that their costs are reimbursable as such. Rather, plaintiff argues that the costs of free care are incidental allowable costs, similar in nature to interest or depreciation, neither of which go directly to benefit medicare patients, but which nonetheless inure as a residual benefit to them and are thus compensable on

62 S. REP. No. 404, 89th Cong., Ist Sess. 48 (1965), reprinted in 1965 U.S. Code Cong. \& AD. News 1943, 1989.

63 The Senate Report indicates that the purpose of the Act is "to provide a hospital insurance program for the aged . . ." S. Rep. No. 404, 89th Cong., 1st Sess. 1 (1965), reprinted in 1965 U.S. Code CoNG. \& AD. News 1943, 1943 (emphasis added).

6442 U.S.C. $\$ 1395 x(v)(1)(A)(i)(1976)$.

65 See, e.g., Indiana Hosp., [1979-2 Transfer Binder] Medicare \& Medrcamo GuDE (CCH) I 30,133, at 9898 . 
that basis. Consequently, defendant's response [is] . . misplaced. . . . ${ }^{66}$

The court in Presbyterian ${ }^{67}$ found the Rapides logic persuasive and went on to state that it was "unable to distinguish [Hill-Burton free care] expenses in principle from interest and other indirect costs" 68 (such as depreciation, interest, research costs, and return on equity).

Hill-Burton care, however, can be distinguished from the other indirect expenses the Presbyterian court cited. The distinguishing factor is that Hill-Burton "costs" are not costs at all, but rather are reductions in revenue under the Medicare accounting system. The Medicare regulations concerning bad debts, charity, and courtesy allowances explain the reasoning: "The failure to collect charges for services rendered does not add to the cost of providing the services. Such costs have already been incurred in the production of the services." 69 Thus, to consider the expense of providing care under the Hill-Burton Act an indirect cost would be to allow a double counting of the actual costs of providing service. ${ }^{70}$ As the PRRB explained in Iredell Memorial Hospital v. Blue Cross Association: ${ }^{71}$

The assumption of a Hill-Burton obligation by the provider does not convert the uncollected revenues into additional reimbursable costs under the Medicare principles of reimbursement. In the cost finding process, costs incurred by the provider in rendering care to all patientsMedicare, Medicaid, private insurors [sic], self-pay, and non-pay-are first determined. These total costs . . . are then apportioned to various classes of patients and Medicare pays its share of these costs. ${ }^{72}$

The Social Security Act vested broad discretion in the Secretary of the Department of Health, Education and Welfare (HEW) to establish cost accounting regulations, ${ }^{73}$ but did require "the Secretary [to] consider, among other things, the principles generally applied by national organizations or established prepayment organi-

66435 F. Supp. at 388.

$67638 \mathrm{~F} .2 \mathrm{~d}$ at 1386.

68 Id. 1387.

6942 C.F.R. $\$ 405.420$ (c) (1981).

70 For an illustration, see infra Appendix. at 9866 .

71 [1981-1 Transfer Binder] Medicare \& Medicam Gume (CCH) \30,930,

72 Id. 9868. For an illustration of this method of computation, see infra Appendix.

73 See 42 U.S.C. $\$ 1395 x(v)(1)(A)$ (1976). 
zations." 74 The American Hospital Association's Principles of Reimbursement had long stated that bad debts, charity, and courtesy allowances were not costs, but rather reductions from revenue. ${ }^{75}$ The Principles did not deal with the question of the status of HillBurton care per se. Nonetheless, the accounting principle of distinguishing between costs and reductions in revenue had been accepted by the American Hospital Association and by Blue Cross. ${ }^{76}$ The treatment of charity was so settled that the drafters of the first Medicare reimbursement guidelines considered excluding charity from allowable costs a "relatively easy" issue."7

The position that Hill-Burton free care is a reimbursable "cost" is grounded in the notion that such care creates a definite financial obligation for the hospital. As the PRRB states in Iredell, however, "[t]he basic root of the issue is that the basis of Medicare payments is actual operating costs as defined by Medicare principles of reimbursement-not the provider's financial requirements." 78 In fact, Medicare does not reimburse for a variety of expenditures that arguably benefit Medicare patients indirectly. For example, if advertising increases the general usage of the hospital, that lowers the per diem costs of all patients, including Medicare patients. Yet Medicare does not reimburse for such expenses. ${ }^{79}$ Similarly, medical research costs are not reimbursable. ${ }^{80}$

This failure to reimburse what arguably are costs of the national health care delivery system stems from the nature of Medicare. The Social Security Amendments of 1965 were designed not to satisfy the financial needs of the health care system but to provide a form of insurance for eligible individuals. ${ }^{81}$ Congress intended Medicare's contribution to the financial well-being of the health care delivery system to be its payment of the actual costs,

$74 I d$.

75 Iredell, [1981-1 Transfer Binder] Medicare \& Medicam Gume (CCF) I 30,930 , at 9868 .

76 Reimbursement Guidelines for Medicare: Hearings Before the Senate Comm. on Finance, 89th Cong., $2 d$ Sess. 45 (1966).

77 Id. 46 (Testimony of Robert M. Ball, Commissioner of Social Security.

${ }^{78}$ Iredell, [1981-1 Transfer Binder] Medicare \& Medrcald Gume (CCH) I 30,930 , at 9868 .

79 Gosman v. United States, 573 F.2d 31, 38 (Ct. Cl. 1978). The court noted that "it is not unreasonable to read both the Act and the general regulationeach pointing directly to the costs incurred in serving Medicare patients-as precluding reimbursement for such indirect expenditures only tangentially or speculatively related to the actual care of Medicare beneficiaries." Id.

80 S. REP. No. 404, 89th Cong., 1st Sess. 36 (1965), reprinted in 1965 U.S. Code Cong. \& AD. NEws 1943, 1977. The report notes that "[a]vailable research funds are generally ample to support important basic medical research." Id.

81 Id. 1-3, 1965 U.S. Code CoNG. \& Ad. NEws at 1943-44. 
both direct and indirect, of care to eligible patients who otherwise would be unable to pay. Noting that paying patients are charged for a portion of the cost of care for nonpaying patients, the Senate report accompanying the Medicare bill emphasized that

careful consideration [was given] to the question of the effect that the proposed program would have on charges to other paying patients. The insurance system will reduce the losses of hospital income from bad debts or for care of free or part-pay aged patients which might otherwise be included in charges to other paying patients by paying the full cost, except for the deductible and coinsurance, for substantially all patients over $65 .^{82}$

Thus Medicare would contribute by paying for otherwise nonpaying Medicare eligibles, not by paying any portion of the cost of ineligible nonpaying patients. As the PRRB explained:

Since Congress was, in effect, removing from local communities and voluntary hospitals the burden of caring for most of the medically indigent, it rightfully expected that those communities and voluntary hospitals would continue to provide a certain amount of charity care to those indigents who would not be covered by either the Medicare or Medicaid Acts. ${ }^{83}$

Thus the argument that Medicare is not paying its fair share of the costs of nonpaying patients, including Hill-Burton patients, overlooks the basic purpose of the Medicare Act. To reimburse hospitals for Hill-Burton care would enlarge the Act in a manner Congress did not intend.

\section{Reimbursement by Medicare Is InCONSISTENT With THE HILl-Burton ACT}

Perhaps the most obvious and fundamental objection to permitting reimbursement by Medicare for Hill-Burton free care is that such reimbursement would subvert a basic purpose of the HillBurton Act. In exchange for receiving funds from the federal government, facilities agree to provide a reasonable volume of care to the indigent. ${ }^{8 t}$ Insofar as the facilities charge the cost of such care to the Medicare program, they are avoiding a portion of their

82 Id. 36-37, 1965 U.S. Code Cong. \& AD. News at 1977 (emphasis added).

83 Florida Hosp. Group Appeal v. Blue Cross Ass'n, [1980 Transfer Binder] Medicare \& Medicam Gume (CCH) $斤 30,374$, at 9415,9422 (Dec. 17, 1979).

8442 U.S.C. $\$ 291 c(e)$ (1976). 
obligations under the Hill-Burton Act. As the court in HarperGrace Hospitals v. Schweiker ${ }^{85}$ stated, "[t]o allow reimbursement for free care provided as a condition to a [construction] grant . . . seems to, in fact, allow a 'double dip' into the funding provided by the Government." 86 Moreover, Medicare reimbursement conflicts not only with the underlying purpose of the Hill-Burton Act, but also with existing Hill-Burton regulations.

\section{A. Hill-Burton Regulations Preclude Medicare Reimbursement for Hill-Burton Free Care}

The Hill-Burton Act gives the Secretary of the HHS (formerly HEW) the power to establish regulations concerning the provision of a "reasonable volume of services to persons unable to pay" by facilities receiving Hill-Burton funds. 87 The current regulations provide that a facility can comply with its free care obligations by providing "uncompensated services" at a level not less than three per cent of its operating costs (excluding Medicare and Medicaid reimbursement) or ten per cent of the amount of federal assistance received under the Hill-Burton program, ${ }^{88}$ whichever is less. The regulations also provide that "[a]ny amount that the facility has received, or is entitled to receive, from a third party insurer or under a governmental program" 89 may not be included in computing the uncompensated services the facility provides.

This provision, excluding from the definition of uncompensated services any amount reimbursable under a federal program, has appeared in basically the same form in the regulations since 1972.90

The hospitals' attempt to obtain Medicare reimbursement may seem puzzling when the effect of reimbursement apparently would be to disqualify such care from being counted towards Hill-Burton obligations. This apparent anomaly, however, does not render the issue moot. First, the Hill-Burton regulation quoted above does not affect those hospitals (such as Presbyterian Hospital of Dallas)

85 [1981-1 Transfer Binder] MEDICARE \& Medicam Gume (CCH) I31,037, at 10,216 (E.D. Mich. Apr. 1, 1981).

86 Id. 10,219.

8742 U.S.C. $\$ 291 c(e)(1976)$.

8842 C.F.R. $\$ 124.503$ (a) (1981).

s9 42 C.F.R. $\$ 124.509$ (1981) (emphasis added). The regulation makes clear that Medicare is included within the definition of "governmental program": "(d) Any amount for which reimbursement would be available under a governmental program (such as medicare or medicaid) in which the facility, although eligible to do so ... does not participate." Id. $\$ 124.509$ (d).

90 See 42 C.F.R. $\$ 53.111$ (f)(2) (1980) (first printed at 42 C.F.R. $\$ 53.111$ (f)(2) (1972) with minor word changes thereafter). 
that satisfied their Hill-Burton obligations via the "open door" option, which was available until September 1, 1979.91 Under this option, hospitals agreed to treat all patients without regard to their ability to pay. Because compliance under the open door option was not tied to a specific level of uncompensated care, the exclusion of care reimbursed by Medicare had no practical effect.

Second, one could argue that the terms of the Hill-Burton regulations cannot control the interpretation of the Medicare Act. Admittedly, the Hill-Burton regulations do not themselves answer the question of reimbursement under Medicare. If, however, the regulations properly reflect Hill-Burton principles, applying the rule of construction requiring statutes to read in a complementary fashion if possible ${ }^{92}$ would indicate that denial of reimbursement is called for.

In addition to the outright ban on including as free care any services that are reimbursed under a governmental program, the definition of costs employed in the Hill-Burton regulations indicates the impropriety of Medicare reimbursement. The regulations permit hospitals to satisfy their free care obligations by providing services to the indigent equal to three per cent of the annual operating costs of the hospital. ${ }^{3}$ Operating costs are defined as the total operating expenses of a facility minus any amount reimbursed by Medicare or Medicaid. ${ }^{94}$

The three per cent presumptive compliance figure was arrived at on the assumption that Medicare and Medicaid would not reimburse any portion of the cost of Hill-Burton free care. ${ }^{95}$ Al-

01 The 1979 regulations, codified at 42 C.F.R. $\$ 124.503$ (a) (1981), eliminated the so-called "open-door option." Under this option hospitals agreed not to turn anyone away for want of the ability to pay for services. For a discussion of the reasons for its elimination, see Appendix I to the Final Rules, 44 Fed. Reg. 29,372, 29,384-86 (1979).

02 Administrator, FAA v. Robertson, 422 U.S. 255, 263, 265-66 (1975).

9342 C.F.R. $\$ 124.503$ (a)(i) (1981).

94 Id. $\$ 124.502$. The following calculation illustrates the method of computing the amount of free care required for presumptive compliance:
Total operating costs
Amount reimbursed by
Medicare and Medicaid
$\$ 1,000,000$
Net operating costs
x 3\% (presumptive compliance percentage)
$\begin{array}{r}-\$ 300,000 \\ \$ 700,000 \\ \times .03 \\ \hline \$ 21,000\end{array}$
Hill-Burton obligation

95 Rose, The Hill-Burton Act-The Interim Regulations and Service to the Poor: A Study in Public Interest Litigation, 6 Clearinghovse Rev. 309, 310 n.18 (1972). It was apparently deemed unfair to apply the percentage to the entire patient population when Medicare and Medicaid would not reimburse any of the 
though one may question whether the reduction for Medicare reimbursement was necessary, ${ }^{96}$ permitting reimbursement would distort the hospitals' obligations by shifting to Medicare a portion of what is already a reduced amount of free care. ${ }^{97}$

Thus, the Hill-Burton regulations preclude Medicare reimbursement. Moreover, reimbursement is inconsistent with the general purpose of the Hill-Burton Act.

\section{B. Reimbursement for Hill-Burton Free Care Is Inconsistent With the Intent of the Hill-Burton Act}

The fundamental problem with permitting Medicare reimbursement for free care provided pursuant to Hill-Burton obligations is that it would undermine one of the central purposes of the Hill-Burton Act. It would effectively permit the hospitals to shift back to the federal government a portion of the cost they agreed to assume in order to receive the initial Hill-Burton funds. This clash with the purpose of the Hill-Burton Act prompted the district court in Harper-Grace to "conclude that Congress [did not intend] for the Medicare program to absorb the cost of indigent care provided as required by Hill-Burton." 98

The objection to the "double-dip" into federal government funds-once for the Hill-Burton funds and a second time for the cost of the Hill-Burton free care obligation-is premised on the assumption that the hospitals originally obligated themselves to assume responsibility for financing the care provided to the indigent as required by Hill-Burton. In fact, one commentator has suggested that the Hill-Burton Act was never designed to obligate the hospitals to finance care for the indigent.99 In Newsom v. Vanderbilt University, ${ }^{100}$ the Sixth Circuit reversed a lower court's

costs of the free care. Id. In the discussion accompanying the publication of the 1979 Final Rules, HEW expressly referred to the Medicare policy of considering Hill-Burton care nonreimbursable charity care. 44 Fed. Reg. 29,409 (1979).

96 See, e.g., Rose, supra note 95 , at $310 \mathrm{n} .18$. If the rationale for the reduction is that the paying patients otherwise would be unduly burdened, see supra note 95, Rose argues that reduction may not be necessary because Medicare and Medicaid have already reduced the burden on paying patients by funding the care of formerly nonpaying patients. See supra text accompanying notes 81-83.

97 The presumptive compliance option of $10 \%$ of the amount of Hill-Burton funds received does not contain an express provision for the Medicare exclusion policy. See 42 C.F.R. $\$ 124.503$ (a)(ii) (1981). Because the options were designed to be roughly equivalent, however, the ten per cent figure probably includes an implied adjustment.

98 Harper-Grace, [1981-1 Transfer Binder] Medicare \& Medicam Gume (CCH) \31,037, at 10,219.

9o See Due Process, supra note 5, at 1476, 1479.

100653 F.2d 1100 (6th Cir. 1981). 
ruling that indigent patients had a constitutionally protected entitlement to free services at Hill-Burton facilities. ${ }^{101}$ In reaching its decision, the court relied in part on its conclusion that " $t]$ he legislative history of the free services provision of the Hill-Burton Act of 1946 demonstrates that Congress had no intention of requiring the hospitals to furnish a certain amount of free care." ${ }^{102}$ This conclusion appears to be based on two other findings: (1) that HillBurton was intended only to provide construction funds, not to combat the problem of health care for the indigent, and (2) that the Act did not intend to make the hospitals liable for funding the provision of free care. ${ }^{103}$ Both of these findings are of questionable validity.

The position that Hill-Burton was simply the first step-the construction phase-of national health care legislation and did not address the problem of providing services finds some support in the historical background surrounding the passage of the Act.104 The original version of the bill that became the Hill-Burton Act did not contain the free care or community service obligations. ${ }^{105}$ It was originally contemplated that Hill-Burton would deal only with construction funding; other problems, including the funding of care, would be dealt with in separate bills. ${ }^{106}$ The proponents of the more limited reading of the Hill-Burton Act draw heavily for support from testimony at the Senate hearings on the Hill-Burton

101 Id. 1117, 1121, 1122.

102 Id. 1119 n.4.

$103 \mathrm{Id}$. 1117,1120 . "A close reading of the legislative history indicates that while there was some concern about providing health care for the poor, having hospitals carry the burden by providing free services is not the answer. The Hill-Burton Act was only a first step to help construct the necessary facilities." Id. 1117.

104 President Truman sent a message to Congress on Nov. 19, 1945, urging the adoption of comprehensive health care legislation. The President's plan called for five phases of legislation: (1) construction of hospitals and related facilities; (2) expansion of public, maternal, and child health services; (3) medical education and research; (4) prepayment of medical costs, and (5) protection against loss in wages from sickness and disability. Message from the President of the United States-Health Legislation, 91 Cong. REc. 10,817, 10,818-20 (1945). In his opening statement at the Senate hearings on the Hill-Burton Act, Senator Hill, its principal sponsor, indicated that the legislation was directed at the first of the problems identified by President Truman-the need for adequate hospital and public health facilities-and as such was only a first step toward solving the nation's health care problems. Hospital Construction Act: Hearings on S. 191 Before the Senate Comm. on Education \& Labor, 79th Cong., 1st Sess. 7 (1945) [hereinafter cited as 1945 Hearings].

1051945 Hearings, supra note 104, at 1-6.

106 See, e.g., S. 1050, 79th Cong., Ist Sess. $\$ \$ 4,9$ (1945), summarized at 91 Conc. Rec. 4924-25 (May 24, 1945); H.R. 3293, 79th Cong., lst Sess. (1945). 
bill. ${ }^{107}$ Although statements at those hearings characterized the bill as one limited to construction, ${ }^{108}$ relying on that testimony is a mistake because the amendments regarding the free care provision were added after the hearings on the bill in its original form. ${ }^{109}$ The meaning of the free care provisions logically cannot be controlled by discussions predating their existence.

Although no legislative history directly pertains to the amendments, which were added during subcommittee executive session, ${ }^{110}$ commentators have suggested that the free care and community service requirements were added out of concern that the other portions of the national health legislation would not be passed.111 Nor does anything in the legislative history of the Act undercut the clear statutory language. The Act as originally passed provided:

[T] he Surgeon General . . . shall by general regulation prescribe-

(f) That the State plan ... shall provide for adequate hospital facilities for persons unable to pay therefor. Such regulation may require that before approval of any application for a hospital or addition to a hospital is recommended by a State agency, assurance shall be received by the State from the applicant that ... (2) there will be made available in each such hospital or addition to a hospital a reasonable volume of hospital services to persons unable to pay therefor, but an exception shall be made if such a requirement is not feasible from a financial standpoint. ${ }^{112}$

This provision clearly requires that services be provided to those patients unable to pay. Although clause (2) is permissive and

107 See, e.g., Newsom, 653 F.2d at $1117-19$ n.4; Due Process, supra note 5, at 1475-80; The Hill-Burton Act, supra note 6, at 320 .

108 The Surgeon General, Dr. Thomas Parran, testified: "S. 191 is silent on the whole question of medical care for people of low incomes. Apparently this was a deliberate omission on the theory that the first and most necessary step is to plan for constructing the most-needed facilities ...." 1945 Hearings, supra note 104 , at 64. Accord, id. 31 (testimony of Dr. Donald C. Smelzer, President of the American Hospital Association).

109 S. Rep. No. 674, 79th Cong., Ist Sess. 1-2, 8-9 (1945).

110 Id. 1-2.

111 See Rose, supra note 4, at 170; Rosenblatt, Health Care Reform and Administrative Law: A Structural Approach, 88 Y ALE L.J. 243, 266 (1978).

112 Hill-Burton Act, Pub. L. No. 725, $\$ 622,60$ Stat. 1040, 1042-43 (1946) (current version at 42 U.S.C. $\$ 291 c$ (e) (1976)) (emphasis added). 
subject to varying interpretations, ${ }^{113}$ the requirement in the first clause that the facilities be available to the indigent is mandatory. In any event, the Surgeon General did issue regulations requiring that assurances of a reasonable volume of care be made available. ${ }^{114}$

Some have argued that the Hill-Burton Act did not intend to place on hospitals the burden of financing care for the indigent. ${ }^{115}$ It is certainly true that the Act did not intend to place the entire burden on the hospitals. This is apparent from the legislative history ${ }^{116}$ and the limitation of free care to a "reasonable volume." 117 Yet the hearings show that the hospitals had been providing a significant amount of free care to the indigent prior to the passage of Hill-Burton. ${ }^{118}$ The requirement that hospitals provide a reasonable volume of free care can most logically be seen as an effort to insure that they would continue the policy of providing free care to the indigent.

The initial regulations provided that the free care could "be paid for wholly or partly out of public funds or contributions of individuals and private and charitable organizations such as community chests or [could] be contributed at the expense of the hospital itself." 119 Permitting the hospitals to seek support in meeting the entire cost of providing a reasonable volume of free care is consistent with the statutory intent. The Act intended to encourage the continued availability of traditional, local, and community charity funding. ${ }^{120}$

113 The court in Newsom reads the second provision to mean that the hospitals themselves are financially obligated for the cost of Hill-Burton care only if the Surgeon General exercises his prerogative under (2). 653 F.2d at 1117 . A more plausible reading, however, is that the Surgeon General must require the state plan to provide for adequate facilities for those unable to pay. Under this view, what is permissive is not the hospital's obligation, but the requirement that each hospital give an assurance before receiving funds. 1947)).

11412 Fed. Reg. 6176, 6179 (1947) (codified at 42 C.F.R. $\$ 53.63$ (Supp.

115 Newsom, 653 F.2d at 1117 \& n.4; Due Process, supra note 5, at 1476.

116 See 1945 Hearings, supra note 104, at 286. At no time during the hearings did anyone suggest that the hospitals were to bear the total cost of care for the indigent. Repeated references were made to the then-existing combination of funding sources-state, local, and charitable-and the participants implied that all of those sources, in addition to the hospitals, would continue to provide funds.

117 See supra text accompanying note 3.

118 The amount of care provided to the indigent was estimated variously at $33 \%$ of the total medical and surgical cases, 1945 Hearings, supra note 104, at 65 (testimony of Dr. Parran concerning pre-World War II years), and at $20 \%$, id. I91 (estimate by Senator Taft). Most of this care, however, was paid for by local communities and by states. Id. 65.

11942 C.F.R. $\$ 53.63$ (Supp. 1947).

120 In response to questioning from Senator Murray, Dr. Smelzer stated that provision of care for those unable to pay "will have to be done at the local level." 
This does not mean, however, that hospitals bear no financial responsibility for providing free care. The statutory section permitting a reduction in the volume of free care in the event of a showing that furnishing such care is not financially feasible ${ }^{121}$ indicates an intention to obligate the hospital to finance free care to the extent that it is financially possible. ${ }^{122}$

Nor does allowing the use of other sources to finance free care obligations indicate that reimbursement by Medicare also would be proper. The initial regulation can be read as being limited to local and state funding. ${ }^{123}$ This is consistent with the intent of Hill-Burton. Although some Senators advocated the use of federal funds to finance care for the poor,,$^{124}$ they were unsuccessful in their attempt to have such a provision included. ${ }^{125}$ To permit reimbursement from federal funds under Medicare, therefore, would conflict with the intent of Hill-Burton that hospitals receiving funds under that Act must provide, in return some free care to those unable to pay.

\section{Policy Considerations and Recommendations}

As this Comment has demonstrated, Medicare reimbursement for free care provided pursuant to Hill-Burton obligations conflicts with the current regulations and with the intent of both the Medicare and Hill-Burton Acts. The question remains whether reimbursement would be wise as a matter of general policy. It has been suggested, not only by the hospitals, but also by those within HEW ${ }^{126}$ that Medicare policy should be changed to permit reimbursement for Hill-Burton free care. Such a change, however, would be ill-advised for a number of reasons.

1945 Hearings, supra note 104, at 30 . Later in the hearings, Senator Ellender indicated that the traditional sources of charity care- "the State, the county, and communities"-could be responsible for paying for care to the indigent if federal funding was not provided. Id. 286.

121 See supra note 112 and accompanying text.

122 The Senate Report states that a waiver of the free care provision is possible if "the hospital is financially unable to undertake such a commitment." S. REP. No. 674, 79th Cong., lst Sess. 9 (1945) (emphasis added).

123 See supra note 120 and text accompanying notes 119-20. Neither Medicare nor Medicaid had been enacted when the 1947 regulations were written.

124 E.g., 1945 Hearings, supra note 104, at 190 . (Senator Pepper recommended the use of a combination of federal, state, and local funds).

125 Rosenblatt, supra note 111 , at 265-66.

126 A Special Assistant to the General Counsel of HEW recommended in a February 1979 memorandum that HCFA change its policy and permit reimbursement. Florida Hosp. Group Appeal v. Blue Cross Ass'n; [1980 Transfer Binder] Medrcare \& Medicam Gume (CCH) \30,374, at 9415 (Dec. 17, 1979). 
First, reimbursement would place an added burden on an already strained Social Security financing system. ${ }^{127}$ The additional expense of Hill-Burton reimbursement would be particularly illtimed in light of recent moves to cut the Social Security budget by reducing benefits. ${ }^{128}$ The drain on Medicaid funding, if Medicare reimbursement were to trigger Medicaid reimbursement, would also be devastating. To place a burden estimated at $50-80 \%$ of $\$ 400$ million per year ${ }^{129}$ (the amount of Hill-Burton uncompensated services required) on the funding systems at this time could be disastrous. ${ }^{130}$

Reimbursement also would be undesirable because it would result in a net reduction in the amount of care available to the poor. Rather than serving as an addition to Medicare and Medicaid, Hill-Burton free care would reduce the funds available under those programs to the extent that they reimburse providers. Moreover, reimbursement for Hill-Burton free care would relieve the hospitals of their legal obligation to provide a "reasonable volume" of care to the indigent in exchange for government funding. It has been suggested that reimbursement may nonetheless be desirable in order to obtain voluntary compliance with free care obligations. ${ }^{131}$ If one assumes that the current regulations cannot or will not be enforced by the current administration, then reimbursement may result in an actual increase in the amount of care available to those unable to pay by encouraging otherwise reluctant hospitals to comply with their Hill-Burton obligations.

The problem with this scenario is that it contemplates the Executive acting in a manner inconsistent with the intent of the statute. In the National Health Planning and Resources Development Act of $1974{ }^{132}$ (which provided new funding for the HillBurton Act), Congress made clear that it intended the free care and

127 The drain would be further exacerbated if reimbursement for Hill-Burton free care triggered reimbursement for other "reasonable costs," such as charity care, provided pursuant to state or local laws. See supra text accompanying notes 50-51.

128 See 4 Medicare \& Medicam Gume (CCH) Last Report Letter May 5, 1981 (discussing proposed cutbacks).

129 Florida Hosp., [1980 Transfer Binder] Medicane \& Medicam Gume (CCH) \f 30,374 , at 9415 .

130 The financial condition of the Medicare and Medicaid funding systems undermines the rationale suggested by the Special Assistant to the General Counsel of HEW, see supra note 126, that reimbursement would be desirable as a means of spreading the cost of care for those unable to pay. See Florida Hospital, [1980 Transfer Binder] MEdicare \& MEDICAID Gume (CCH) \{ 30,374, at 9415.

131' Id.

132 Pub. L. No. 93-641, 88 Stat. 2225 (1975) (current version at 42 U.S.C. \$ 300q-300t (1976 \& Supp. III 1979)). 
community service obligations to be vigorously enforced. ${ }^{133}$ The Executive is not free to disregard statutory mandates when administering a law..$^{134}$ Moreover, to suggest that the hospitals should be given a "sweetener" to induce them to comply with their legal obligation is offensive.

Nor is it in any sense unfair to hold hospitals to their free care obligations. At the time Hill-Burton was enacted, it was estimated that $20-33 \%$ of the total services rendered were to persons unable to pay. ${ }^{135}$ Because the burden on the hospitals has since been reduced by Medicare and Medicaid, ${ }^{136}$ it is reasonable to expect that some responsibility for caring for those unable to pay should remain.

It has been suggested that Medicare reimbursement would be warranted as a means of reducing administrative costs. ${ }^{137}$ The provision of Hill-Burton free care could be monitored by those administering the Medicare program, thus eliminating the need for separate enforcement personnel. Although such a plan probably would result in some savings, nothing would seem to prevent the use of the Medicare reimbursement mechanism to monitor HillBurton obligations in their present form. Certainly any potential savings in administrative costs are far outweighed by the considerations previously discussed.

On the whole, retention of the current reimbursement policy is sound. The regulations, however, should be amended to remove any doubt concerning the propriety of reimbursement. This can be achieved simply by amending the Medicare regulations regarding charity care ${ }^{138}$ expressly to encompass care provided under HillBurton. Alternatively, Congress could amend the statute expressly to classify Hill-Burton free care as a provision of services to those

133 The provision of the Hill-Burton Act that the regulations "may" require that a hospital give assurances of free care prior to receiving funds, 42 U.S.C. $\$ 291 \mathrm{c}$ (e) (1976), was changed to read "shall," 42 U.S.C. $\$ 300$ s-1(b)(1) (Supp. III 1979). The report accompanying the final bill expressly states that the change was made because of the "sorry performance . . . in implementing a provision which has been in law for over 20 years, and has recently been reemphasized." S. Rep. No. 1285, 93d Cong., $2 d$ Sess. 61, reprinted in 1974 U.S. ConE Cong. \& An. News 7842, 7900. The new language applies only to funds dispersed under the new act.

134 See, e.g., Industrial Union Dep't v. American Petroleum Inst., 448 U.S. 607 (1980) (invalidating OSHA regulations because Secretary of Labor disobeyed statutory mandate to make certain findings with respect to the risk of workplace exposure to benzene).

135 See supra note 118.

136 See supra note 82 and accompanying text.

137 Florida Hosp., [1980 Transfer Binder] MEdicAre \& MEdrcam Gume (CCH) II 30,374 , at 9415 .

138 See supra note 40. 
not legally obligated to pay. The Hill-Burton regulations as they currently exist preclude reimbursement ${ }^{139}$ and therefore do not need to be altered. An express statutory provision prohibiting hospitals from including care reimbursed by Medicare would be desirable because it would remove any doubt about the propriety of the regulations.

\section{Conclusion}

This Comment has argued that Medicare reimbursement by Hill-Burton costs not only would be contrary to law but also would be inappropriate. Such reimbursement would violate existing Medicare regulations as well as the policy underlying Medicare. In addition, reimbursement conflicts with existing Hill-Burton regulations and the underlying policy of that Act. Even absent any violation of the Medicare and Hill-Burton Acts, strong policy reasons support denying reimbursement. Undoubtedly a need exists for a source of funding for the care of those who are unable to pay and who do not meet the eligibility requirements of Medicare or Medicaid. Medicare reimbursement, however, is not the appropriate means of accomplishing this task. The problem of inadequate health care funding demands a more suitable solutionfor example, a national health insurance program-rather than the distortion of existing legislation.

139 See supra notes 87-97 and accompanying text. 


\section{APPENDIX}

Both methods described below assume the following yearly patient utilization:

Total Patient Days

(Thousands)

Patient Days Attributable to Hill-Burton Indigents 100

Patient Days Attributable to Medicare Patients

50

\section{Method $I^{140}$}

1. Actual total cost of providing care to all patients (including direct and indirect costs)

(Thousands)

2. Cost attributable to Hill-Burton patients

3. Cost attributable to non-Hill-Burton patients

4. Hypothetical cost of providing care to all patients

based on providers' contentions (lines $1 \& 2$ )

5. Medicare patient utilization

6. Payment under current Medicare principles

of reimbursement (lines $1 \& 5$ )

$\$ 1,000$

$\$ 30$

$\$ 970$

$\$ 1,030$

$50 \%$

$\$ 500$

$\$ 515$

7. Payment sought by providers (lines $4 \& 5$ )

Under Method I, as proposed by the providers in Iredell Memorial Hospital v. Blue Cross Association, ${ }^{141}$ the costs associated with providing Hill-Burton care, although already included in the total cost figure in line 1 , are added to the total costs as an additional, hypothetical cost.

Noting that Method 1 results in the appearance of a double counting of Hill-Burton patient costs, the providers in John Muir Memorial Hospital v. Blue Cross Association, ${ }^{142}$ proposed the following alternative:

\section{Method 2}

1. Actual total cost

(Thousands)

2. Medicare patient utilization under current method $(50 \div 100)$

3. Proposed Medicare patient utilization excluding Hill-Burton patient days $(50 \div(100-3))$

4. Proposed reimbursement

$\$ 1,000$

$50 \%$

\section{$51.55 \%$}

$\$ 515$

140 Adapted from Iredell Memorial Hosp. v. Blue Cross Ass'n., [1981-1 Transfer Binder] MEDICARE \& MEDICAID GuIDE (CCH) $\llbracket$ 30,930, at 9866, 9868 (Mar. 6, 1981).

141 Id.

1424 Medicare \& Medicam Gume (CCH) \31,492, at 9443 (Aug. 26, 1981). 
Method 2 retains the actual total cost figure and instead adjusts the patient days (step 3). It removes the Hill-Burton patient days in determining Medicare utilization on the theory that HillBurton patients cannot properly be considered either Medicare or non-Medicare patients. By excluding Hill-Burton patient days from the non-Medicare patient days, the Medicare utilization percentage is increased. Thus, Method 2 results in virtually the same level of reimbursement as Method 1. 